Acta medico-historica Rigensia (2010) IX:287-297

DOI: 10.25143/amhr.2010.IX.17

\title{
23. Starptautiskajā Baltijas zinātņu vēstures konferencē
}

\author{
Jānis Stradinš
}

2008. gada 9.-10. oktobrī Rīgā notika tradicionālā 23. Starptautiskā Baltijas zinātņu vēstures konference. Tā bija veltìta triju Baltijas valstu neatkarības 90 gadu jubilejai, kā arī 50 gadiem, kopš sākusies Baltijas zinātṇu vēstures konferenču tradīcija, atjaunots Rìgas Politehniskais institūts (1958. gada 1. septembrī, tag. Rìgas Tehniskā universitāte, RTU) un oficiāli nodibināts P. Stradiṇa Medicīnas vēstures muzejs (1957. gada septembrī, kopš 1958. gada 18. augusta nosaukts dibinātāja Paula Stradiṇa vārdā). Konferenci rīkoja Baltijas valstu Zinātṇu vēstures un filozofijas asociācija, Latvijas Zinātṇu akadēmija, Rīgas Tehniskā universitāte, Latvijas Universitāte, Paula Stradiṇa Medicīnas vēstures muzejs. Rīkotāju vidū bija Latvijas Zinātṇu vēstures asociācija, kas arī dibināta tieši pirms 50 gadiem, 1958. gada janvārī. Savā ziṇā šì konference bija ārpuskārtas konference saistībā ar minētajām jubilejām, tādēl arī referātu un dalībnieku skaits bija nedaudz limitēts, salīdzinot ar iepriekšējām. Taču pieteikto referātu kopskaits, kas publicēti materiālu krājumā "Nova Miscellanea Historiae Scientiarum Baltica - 50", bija 83, no tiem reāli noklausīti vai prezentēti 55 referāti. Konferencē piedalījās zinātṇu vēsturnieki no 11 valstīm (Vācija, Lielbritānija, Austrija, Portugāle, Krievija, Ukraina, Baltkrievija, Somija, Igaunija, Lietuva, Latvija), referentu un klausītāju kopskaits divās plenārsēdēs un sešās sekciju sēdēs pārsniedza 150-200 cilvēkus.

Pirmā plenārsēde notika RTU Lielajā aulā. To atklāja RTU rektors akadēmiḳis profesors Ivars Knēts. Tika nolasīts izglìtības un zinātnes ministres prof. Tatjanas Koḳes apsveikums konferencei un Baltijas Zinātṇu vēstures un filozofijas asociācijas prezidentam prof. J. Stradiņam pasniegts T. Koḳes parakstìts Ministrijas Atzinības raksts par ilggadēju un rezultatīvu darbu Latvijas, Baltijas un Eiropas zinātnes vēstures pētniecỉbā, par Baltijas zinātniskā darba organizēšanu un aktivizēšanu. LZA prezidents akadēmiķis Juris Ekmanis ievadvārdos izteica gandarijumu par zinātnieku interesi un atsaucību, pievēršoties dažādu zinātṇu nozaru vēstures pētniecībai. Šì aktivitāte vēlreiz apliecina ES attīstības politikā akcentēto 


\section{J. Stradiň̌}

tēzi par "zinātnes sabiedrības" veidošanas aktualitāti ES dalībvalstīm. Zināšanas nav domājamas bez sistemātiskas, uz pirmavotiem balstītas pētniecības. Ir simboliski, ka Baltijas valstiskuma veidošanos saista ar zinātnes un augstākās izglītỉbas problēmu analīzi, izcilu vietējo zinātnieku darbỉbas atceri un godināšanu. Prezidents ierosināja, lai par laikmeta ietekmi uz zinātnes un augstākās izglìtības attīstību, par zinātnisko skolu veidošanos, par Baltijas cel̦u uz Eiropu un Eiropas ietekmi Baltijā, par izcilajām, radošajām personībām sastādītu kopējus plašākus darbus - lai apkopotu vēsturisko pieredzi un apzinātu nākotnes perspektīvas pētniecībai Baltijā.

Ievadreferātu par Baltijas zinātņu vēstures konferenču 50 gadiem (1958-2008) nolasīja akadēmiķis Jānis Stradiņšs, ieskicējot gan vēsturiskos priekšnoteikumus šādu konferenču rīkošanai, gan sīkāk iztirzājot pirmās konferences sarīkošanu (ko sasauca Rīgā 1958. gada 6.-7. jūnijā pēc prof. Paula Stradiṇa ierosmes un kuras organizēšanā piedalījies arī pats ievadreferāta autors), runājot arī par turpmāko konferenču norisi. Referents izcēla šo konferenču nozimību Baltijas republiku zinātnieku vienošanai, brīvdomīgas gaisotnes uzturēšanai un "garīgai pretestībai" pret sovjetisko unifikāciju. Tika atzīmēts, ka jau 1990. gada 29. oktobrī Rīgā nodibināta Baltijas valstu Zinātņu vēstures un filozofijas asociācija, kuras prezidents 1991. gada janvārī vērsās ar radiovēstījumu zinātnes pasaulei, lai protestētu pret padomju armijas brutālajām akcijām Viḷnā un solidarizētos ar Lietuvu. Iezīmēta turpmākā konferenču norise jau atgūtās neatkarības apstākḷ̆os (1991. gada 4.-6. oktobrī Viḷnā notika 16. Baltijas Zinātṇu vēstures konference, kas bija pirmais Baltijas zinātnieku saiets vispār pēc valstu neatkarības atgūšanas), kā arī šo konferenču nākotnes izredzes sakarā ar paaudžu maiņu zinātnes vēsturnieku vidē. Tika parādīti daudzi dokumenti un fotoattēli šo konferenču pusgadsimta pieredzes raksturošanai.

Plašu, labi dokumentētu un ilustrētu materiālu par augstāko inženierizglìtību Latvijā cauri gadsimtiem, raksturojot Rīgas Politehnikuma (Rīgas Politehniskā institūta, LU tehnisko fakultāšu un atjaunotā Rīgas Politehniskā institūta) vēstures galvenos momentus un pašreizējo situāciju nolasijja RTU rektors profesors Ivars Knēts. Referātu par 20. gadsimtu kā liktenīgu notikumu un pagrieziena gadsimtu Baltijas valstu vēsturē, īpaši pievēršoties zinātnes attīstības periodizācijai Lietuvā kopš 1907. gada saistībā ar sociāli politiskām norisēm, nolasỉja Lietuvas Zinātṇu vēstures un filozofijas asociācijas prezidents Jozs Algimants Krikštopaitis (Viḷna). Igaunijas ZA akadēmiķa Karla Sīlivaska (Tallina) referāts par Baltijas jūras reǵiona zinātniskās dzīves kopīgo iezīmju raksturojumu 17.-19. gs. netika nolasìts referenta slimības dēl, taču tā pilns teksts publicēts konferences materiālu krājumā.

Sakarā ar Latvijas Zinātṇu vēstures asociācijas pastāvēšanas 50 gadiem tika pasniegti šìs asociācijas Goda biedru diplomi profesoram L. Klimkam (Viḷna), rektoram I. Knētam (Rìga) un Dr. H. Tankleram (Tartu, diplomu sañēma prof. R. Vihalems, jo Tanklers konferences priekšvakarā bija aizgājis mūžībā). Nosaukumu piešķīiris savā 2008. gada 16. septembra sēdē LZA Senāts, kura pārraudzībā darbo- 


\section{Starptautiskajā Baltijas zinātṇu vēstures konferencē}

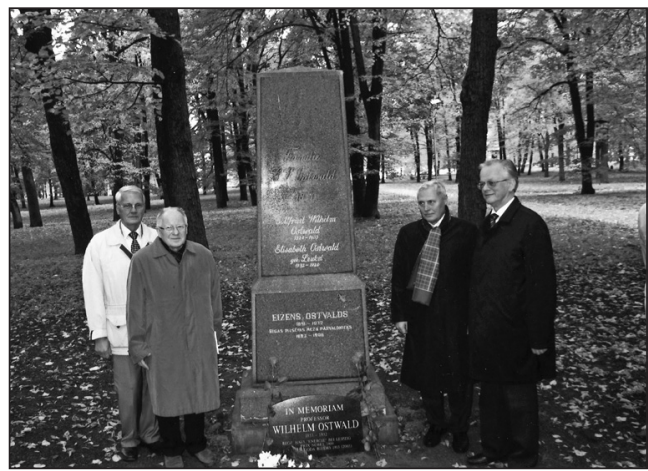

Konferences noslēgumā Rīgas Lielajos kapos atklāj renovēto Ostvaldu dzimtas kapa pieminekli ar piemiñas zīmi Nobela prēmijas laureātam, Rīgas kịmiķim Vilhelmam Ostvaldam, kuru sponsorējusi firma ITERA-Latvija un tās prezidents J. Savickis. No kreisās: akad. I. Knēts, akad. J. Stradiňš, ITERA prezidents J. Savickis, LZA prezidents J. Ekmanis

Konferences atklāšanas sēdē 2008. g. Baltijas zinātṇu vēstures un filozofijas asociācijas prezidents akad. J. Stradiņš nolasa lēmumu par

Latvijas Zinātṇu vēstures asociācijas goda biedra nosaukuma piešķiršanu RTU rektoram I. Knētam. No kreisās: LZA prezidents J. Ekmanis, akad. J. Stradiņšs, akad. I. Knēts

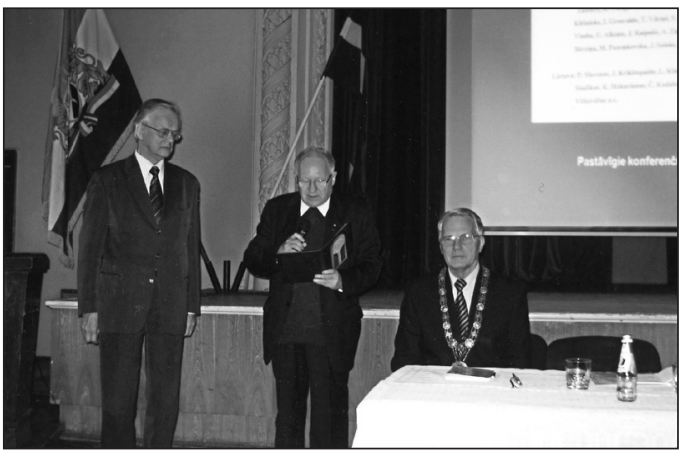

jas minētā asociācija. Vēl līdzīgi diplomi šajā reizē piešķirti hologrāfijas izgudrotājam prof. J. Upatniekam (ASV), emeritētajam k̦īmijas profesoram J. Lielmežam (Kanāda) un G. Brauerei, Vilhelma Ostvalda mazmeitai, kas dzīvojusi Vācijā Ostvalda muzejā - mītnē "Enerǵija" un piedalījusies sava vectēva zinātniskā un materiālā mantojuma saglabāšanā. Plenārsēdes noslēgumā RTU rektors rīkoja pieņemšanu konferences dalibniekiem.

Sekcija "Zinātne un sabiedrība" darbojās RTU doc. J. Klētnieka un prof. L. Klimkas vadībā. T. Kīskinenas (Helsinki) referāts bija veltīts tēmai par meteoroloǵiju un politiku - tika analizēti zviedru astronoma un garīdznieka S. A. Forsija 1594.-1596. gada vērojumi par Tallinā novēroto komētu un citām parādībām, saistot tās ar kara paredzēšanu. Divi igauņu referāti bija veltīti zinātnes filozofijai - L. Nepinens (Tallina) referēja par matemātikas pielietojumu dabas izpratnei, bet prof. P. Mīriseps (Tallina) - par katastrofu teoriju un tās atdzimšanu laika gaitā. L. Lepika (Tallina) nolasīja interesantu ziņojumu par zinātnes popu- 
larizēěanu Igaunijas Republikā 1920.-1940. gadā, V. Pocjus (Viḷna) pastāstīja par vecā RPI un tur funkcionējošās lietuviešu studentu organizācijas "Viltis" nozīmi Lietuvas zinātnei un kultūrai. A. Vasiḷauskiene (Šauḷi) nolasīja divus referātus par Lietuvas Katoḷu akadēmiju un katoḷu garīdznieku V. Uštupa un S. Ilas darbïbu, bet prof. L. Klimka - par Latvijas lietuvēs darinātajiem zvaniem Lietuvas un Latvijas katoḷu baznīcām. Divi referāti - A. Kukela (Rīga) un J. Klētnieks (Rīga) bija veltīti autoru pazistamajiem Éğiptes piramìdu (Džosera piramìdas) pētijumiem ar modernajām mērījumu sistēmām. Turklāt J. Klētnieks iztirzāja arī Džosera piramỉdas garīgumu un vispār seno ēǵiptiešu priekšstatus par mūžỉbu, mirušo valstỉbu un astronomiju. Latvijas pētnieku darbs egíptologijā izpelnījies starptautisku ievērību, bet J. Klētnieka pārdomas iekḷautas viṇa izcilajā grāmatā "Mūžības valdnieki", kas nākusi klajā tūdalı pēc konferences.

Dabaszinātṇu un inženierzinātņu vēstures sekcijā, kas strādāja LU Dr. Ilgoṇa Vilka vadībā, noklausījās K. Bēra muzeja vadītāja Erki Tamiksāra (Tartu) referātu par Sibīrijas mamutu un mūžīgā sasaluma pētījumiem 19. gs., kur liela bijusi Igaunijas zinātnieku (K. E. Bēra, A. Midendorfa) loma. J. Baņonis (Viḷna) ziṇoja par A. Jakšta-Dambrauska nopelniem matemātikas attīstībā Lietuvā, bet N. M. Diasa un līdzautoru (Koimbra, Portugalē) referāts bija veltīts Tartu botāniķa H. M. Vilkoma savāktās Ibērijas augu herbāriju kolekcijai. I. Šperberga un U. Sedmalis (Rīga) referēja par keramikas kīmiju un tehnolog̣iju Latvijā kopš 1863. gada līdz mūsdienām, bet Dr. I. Grosvalds (Rīga) - par ḳīmiskās rūpniecības attīstību Latvijā no 1918. līdz 1944. gadam. L. Petrauskiene (Viḷna) aplūkoja jautājumu, kurš ir bijis dēḷ barometra izgudrotājs 18. gs., bet J. Olehnovičiene - ihtiologisko pētijumu attīstību Lietuvā. N. Avakjana (Sanktpēterburga) savu referātu veltīja ievērojamam 19. gs. sākuma naturālistam J. G. Fišeram-Valdheimam, pirmās Dabaspētnieku biedrības dibinātājam Krievijā. Daudzi citi sekcijā pieteiktie referāti diemžēl izpalika referentu neierašanās dēḷ.

Pedagog̣ijas vēstures sekciju, kuras sēdes notika LU Pedagoǵijas muzejā Anniņmuižā, vadīja Dr. Alīda Zigmunde. Referāti skāra g. k. Latvijas pedagoǵijas vēstures un metodolog̣ijas problēmas. Bija prof. R. Garlejas referāts par pedagoğiju un izglìības kvalitāti, prof. I. Ķesteres referāts par pedagoǵijas kā disciplīnas veidošanos Latvijā, prof. A. Krūzes referāts par izglìtības vēstures pētijjumiem Latvijā pēc neatkarības atgūšanas. Divi referāti bija veltīti senākas pagātnes notikumiem A. Staris (Rīga) nolasīja referātu par pirmo reālǵimnāziju Rīgā (1861-1873) saistỉbā ar RP tapšanu, bet A. Zigmunde - par J. G. Struenci kā pirmo kurlmēmo skolu pasniedzēju sagatavotāju Latvijā. L. Klimkas un R. Kivilšienes (Viḷna) referāts bija veltīts mācību sistēmai piāru ordeņa skolās Lietuvā 18.-19. gs., bet A. Lankas un A. Zigmundes (Rìga) referāts bija veltīts pavisam mūsdienīgam tematam - pedagoǵijas studijām RTU Humanitāro zinātṇu institūtā.

Kā allaž, skaitliski lielākā un rosīgākā bija Medicīnas vēstures un muzeologijas sekcija, kas pulcējās Medicīnas vēstures muzejā direktores E. Bērziṇas un Dr. M. Pozemkovskas vadībā. Notika divas piemiņas sēdes. Pirmā tika veltìta 
ilggadējā muzeja direktora docenta Dr. h. c. K. Ė. Arona (1933-2005) piemiņai, kuram šogad apritētu 75 gadi, bet otra - muzeja dibinātāja un Baltijas zinātṇu vēstures konferenču iniciatora prof. P. Stradiña (1896-1958) piemiņai. Plaša un emocionāli bagāta izvērtās K. Arona piemiṇas sēde, ko ievadỉja prof. Jura Salaka referāts par K. E. Arona daudzpusīgo un spilgto personību. M. Pozemkovska raksturoja Muzeja attīstību 50 gados un tā šodienu. Pazīstamais medicīnas vēsturnieks prof. K. Vasiljjevs (Odesa), kurš bija piedalījies ar referātu jau pirmajā Baltijas konferencē pirms 50 gadiem, strādādams tolaik Rīgā, sniedza pārdomātu, kaut arī lıti subjektīvu Baltijas konferenču tematikas izvērtējumu 1958.-2006. gadā, runāja par šo konferenču nākotni, par nacionālā un internacionālā saistību medicīnas vēsturēe par Baltijas "tilta" funkcijām. J. Stradiṇa un Dz. Cēberes referātā tika aplūkota Paula Stradiņa Medicinas vēstures muzeja genēze un agrīnais attīstības posms, kad muzejs formāli darbojās Latvijas PSR ZA Bioloǵijas un eksperimentālās medicīnas institūta sastāvā (1946-1952); tika analizēts neīstenots Latvijas PSR Ministru Padomes lēmumprojekts (1946. g. augustā) par šì institūta sadalīšanu divos institūtos un atsevišksa medicīnas vēstures muzeja kā ZA autonomas vienības izveidošanu.

Paula Stradiṇa piemiṇas sēdē akadēmiḳis prof. A. Vỉksna referēja par Latvijas medicinas vēstures tematikas iztirzāšanu Baltijas zinātņu vēstures konferencēs (1958-2006), bet prof. J. Salaks - par Medicinas vēstures muzeja starptautiskajiem kontaktiem. V. Sjüdiks, T. Meks un Z. Šimantiene (Kauņa) raksturoja Lietuvas Medicinas un Farmācijas muzeja sadarbību ar Paula Stradiņa muzeju Rīgā, bet M. Livi-Kalninas (Tartu) un A. Vỉksnas kopziņojums bija veltīts vadošā igauņu medicīnas vēsturnieka Viktora Kalnina aktīvajai līdzdalïbai Baltijas zinātņu vēstures konferencēs. Dr. B. Felders (Tïbingena) raksturoja priekšstatus par iedzimtības higiēnu (rase, tautība, psihiatrija) Latvijā 1937.-1944. gadā. Arī K. Kallinga (Tartu) lekcija par psihiatriskajām slimnīcām Igaunijā nacistu okupācijas laikā (1941-1944), kas gan tika nolasìta zinātnes un sabiedrības sekcijā, bija veltìta nacistu rasu teoriju praktiskajām konsekvencēm. J. Dupḷenko un N̦. Kočubejas (Kijeva) referāts skāra oftalmologijas attīstību Ukrainā un Latvijā 20. gs. pirmajā ceturksnī - paralēlēm un sadurēm. O. Kuḷpanoviča (Minska) runāja par veselības aizsardzības ekonomiku kā darbības jomu, tās ğenēzi un vēsturisko attīstību, bet V. Kuzṇecovs (Rīga) - par psihiski slimo slimnieku patversmi un pārmācības namu Rìgas citadelē (1787-1823), tā kārtỉbas noteikumiem.

Pazīstamā somu dabaszinātṇu vēsturnieka LZA ārzemju locekḷa prof. A. Leikolas (Helsinki) referāts vēstīja par E. J. Bonsdorfu kā anatomijas celmlauzi Somijā, A. Ričkiene (Viļña) analizēja dažus vēstures avotus par Viḷnas Universitātes farmaceitu darbību botānikā. A. Ruplis (Rìga) demonstrēja savu muzeja digitalizācijas projektu.

Noslēguma plenārsēde un humanitāro zinātṇu sekcijas sēde notika Latvijas Akadēmiskās (Misiņa) bibliotēkas lielajā zālē. Humanitāro zinātṇu sekcija prof. A. Cimdinasas un prof. V. Muktupāvela vadībā notika kā "Letonikas gada" 


\section{J. Stradiň̌}

starptautisks pasākums. Doc. S. Kḷaviņas referāts sniedza pārskatu par latviešu valodniecības sākumiem (19. gs. vidus-1930. gads), raksturojot gan baltvācu devumu latviešu valodniecībā (A. Bīlenšteina gramatikas tapšanu), gan pirmā latviešu valodnieka ārsta J. Bāra nopelnus, gan jaunlatviešu pienesumu (J. Alunāns, K. Valdemārs, A. Kronvalds, K. Biezbārdis u. c.), Rīgas Latviešu biedrības Zinību komisijas un tās pārskatu ar LU Filolog̣ijas fakultātes un tās baltu nodaḷas dibināšanu un J. Endzelīna "Lettische Grammatik" (1922) iznākšanu. Prof. J. Štrauhmanis savukārt pievērsās vēsturisko atlantu veidošanas problēmām, izceḷot nepieciešamïbu sagatavot kopēju Latvijas, Lietuvas un Igaunijas vēsturisku atlantu, kas atbilstu mūsdienu prasībām. Pauls Daija (Rīga) referēja par Apgaismības laikmetā izdoto M. Štobes "Latvisku Gadagrāmatu" (1797-1798), kuras saturs bija populārzinātnisks, diezgan detalizēti iztirzājot šì izdevuma tematiku. Igauṇu pētnieka A. Rēmera un pāragri mirušā $\mathrm{H}$. Tanklera (Tartu) kopējā referātā bija aplūkoti zviedru-igauṇu kontakti humanitāro zinātņu jomā 1920.-30. gados, bet J. Lilja (Tampere, Somija) skāra divu Somijas literāro biedrību publikāciju starptautisko rezonansi kopš biedrību dibināšanas 19. gs. pirmajā pusē līdz 2. Pasaules kara sākumam. J. Stradiṇa un Dz. Cēberes referātā bija aplūkotas Maskavas latviešu pulciņa 1880. gados iedibinātās prēmijas par populārzinātniskiem darbiem dabaszinātnēs un vēstures zinātnēs. İpaši izcelta t. s. Reinberga prēmija, ko par F. Brīvzemnieka ziedotiem finanšu līdzekḷiem piešķīra 1886.-1889. gadā; tās saṇēmēju skaitā bija J. Krodznieks, V. Olavs, Skruzī̌su Mikus. Sīkāk tika iztirzāts arī maskaviešu prēmijas piešķiršanas fakts Tērbatas studentam dzejniekam Eduardam Veidenbaumam 1892. gadā par apjomīgo rokrakstu "Apcerējumi par mehāniku". Referātā tika ierosināts Latvijā iedibināt Kr. Valdemāra un Kr. Barona balvas (prēmijas) dižo Atmodas laika darbinieku un pirmo latviešu zinātnes sponsoru piemiņas iemūžināšanai. LU Filolog̣ijas un mākslas zinātṇu fakultātes dekāne prof. A. Cimdiṇa papildināja šo domu ar ierosinājumu iedibināt E. Veidenbauma stipendiju radošiem studentiem, ko varētu īstenot sakarā ar LU 90. gadadienu 2009. gadā.

Šajā sekcijā arī A. Zigmunde (Rìga) un Vinfrīds J. Šellers nolasīja referātu par latvieti Jūliju Kalēju (Kuzṇecovu), viña saskarēm ar Lietuvu, Latviju un Samarkandu, kur šis īpatnējais filologs un Krievijas G̣eogrāfijas biedrïbas biedrs mira 1905. gadā. İpatnējs un saistošs bija Jura Baldunčika un Guntas Ločmeles referāts par avižu sludinājumiem un to nozīmi latviešu valodas attīstībā, sākot ar K. Vatsona "Latviešu Avīzēm" (1822) līdz mūsdienām.

Noslēguma plenārsēdē LZA viceprezidente, LU Latviešu valodas institūta direktore akadēmik̦e Ilga Jansone sniedza pārskatu par valsts pētijumu programmu "Letonika", tās ritējumu, par "Letonikas" gada iecerēm un to risinājumu. LZA prezidents Juris Ekmanis kopā ar Dr. A. Dravenieci veidotajā, labi strukturētajā referātā iztirzāja zinātniskās sadarbības problēmas Baltijas jūras valstīs, īpaši sadarbïbu starp trim Baltijas valstīm un arī par to sadarbỉbu ar Ziemel̦valstīm. Tika raksturotas kopējas pētnieciskās programmas, ieskicēta Baltijas intelektuālās sadarbības konferenču vēsture (iedibinātas 1935. gadā, atjaunotas kopš 1999. gada), 
pieminēta arī kopīgas triju Baltijas ZA medal̦as iedibināšana un piešķiršana (kopš 1999. gada). Tika izcelta Latvijas ZA iniciatīva šo ieceru izvirzišanā un īstenošanā.

Plenārsēdi noslēdza Tartu Universitātes profesora Reina Vihalema referāts par teorētisko filozofiju un zinātnes filozofiju padomju laikā (1960-1990. gadā), kurā referents centās atbildēt uz jautājumu, kāda ir šajā nozarē veikto tālaika pētījumu paliekamā zinātniskā vērtība. Pēc prof. Vihalema domām, vienlaikus ar dogmatiskiem uzstādījumiem un ideologisku tukšvārdību vairākos darbos rodamas idejas, kas nav zaudējušas savu nozīmību. İpaši tas sakāms par pētījumiem, kuros iztirzāti agrīnie K. Marksa darbi (piemēram, tēzes par L. Feierbahu), domas par praksi kā zinātniskās patiesības kritēriju.

Sēdes beigās notika Baltijas Zinātṇu vēstures un filozofijas asociācijas G̣enerālās asamblejas sēde, kurā līdzšinējais prezidents Latvijas pārstāvis J. Stradiņš nodeva savas pilnvaras Igaunijas pārstāvjiem. Par Asociācijas darbības dažādām pusēm un tās nākotnes redzējumu viedokḷus izteica E. Tamiksārs, J. Krikštopaitis, P. Mīriseps, J. Salaks, A. Leikola, J. Stradiņš un citi. Tika izsacìts ierosinājums saskaņot turpmāko Baltijas konferenču norisi ar Ziemel̦valstu simpozijiem par zinātnes un ideju vēsturi, kas gan nav rỉkoti kopš 1991. gada, bet ko paredzējuši atsākt somi 2010. gada augustā. Taču asambleja nosliecās par labu Igaunijas pārstāvju iniciatīvai turpināt līdzšinējo Baltijas zinātṇu vēstures konferenču rīkošanas praksi kopā ar medicīnas vēsturniekiem, bez šaubām, padzilinot kontaktus ar Ziemel̦valstu zinātṇu vēsturniekiem. Nākamo Baltijas Zinātṇu vēstures konferenci iecerēts rīkot 2010. gada oktobrī Tallinā uz Tallinas Tehniskās universitātes bāzes, tematikā iekḷaujot arī zinātnes filozofijas problēmas lielākā mērā, nekā tas darīts līdzšinējās Baltijas zinātņu vēstures konferencēs. Kā konferences potenciālie rīkotāji minēti Dr. E. Tamiksārs un prof. P. Mīriseps, kas ir jaunākās paaudzes igauṇu zinātņu vēsturnieki un filozofi.

Baltijas Asociācijas padomē tika ievēlēti J. Āvikso (prezidents), P. Mīrseps, R. Vihalems, E. Tamiksārs, J. Stradiņš (viceprezidents), I. Knēts, J. Klētnieks, J. Salaks, A. Vìksna, A. Zigmunde, J. A. Krikštopaitis (viceprezidents), R. Kondratas, J. Baņonis, K. Makarjūns, A. Andrjušis, L. Klimka, E. Adomonis. Asociācijas pārstāvis ASV ir R. Šviedris, Ziemel̦valstīs - A. Leikola. Tāpat G̦enerālajā asamblejā bez nākamās (24.) konferences noturēšanas Tallinā (2010. gada oktobrī) tika nolemts sadarboties ar Ziemel̦valstu konferences organizētājiem Helsinkos (2010. gada augustā), un līdz 2010. gada oktobrim izstrādāt formālus priekšlikumus par kopēju Baltijas-Ziemel̦valstu zinātṇu vēstures konferenču saskaņošanu.

Pēc G̣enerālās asamblejas notika plašas grāmatu un dokumentu izstādes atklāšana Latvijas Akadēmiskajā (Misiṇa) bibliotēkā, ko organizējusi bibliotēkas darbiniece Arta Poriete kopāa ar Latvijas Zinātṇu vēstures asociāciju. Izstāde aptver izdevumus no 18. gs. līdz mūsdienām, gan - senas grāmatas un arī rokrakstus, gan visu Baltijas zinātṇu vēstures konferenču programmas, tēzes, ielūgumus, rokrakstus, kas raksturo Baltijas Zinātṇu vēstures un filozofijas asociācijas darbu, Jāṇa 


\section{J. Stradiň̌}

Strupuḷa veidotas zinātnieku medaļas, Latvijas, Lietuvas un Igaunijas zinātṇu vēsturnieku grāmatas, rakstu krājumus, cita veida publikācijas, J. Klētnieka, J. Stradiņa u. c. zinātn̦u vēsturnieku personiskos materiālus. Izstāde ir bagāta, veidota ar lielu rūpỉbu. Tà liek atcerēties pirmajā 1958. gada konferencē sarîkoto zinātnisko grāmatu izstādi, ko bija veidojusi toreizējās Latvijas PSR ZA Fundamentālās bibliotēkas darbiniece Meta Taube (saglabājušies ieraksti viṇas dienasgrāmatā par šo izstādi). Izstādes atklāšanā runāja Akadēmiskās bibliotēkas direktore Dr. h. c. Venta Kocere, LZA prezidents J. Ekmanis, Latvijas Zinātṇu vēstures asociācijas prezidents J. Stradiņš, izstādes veidotāja A. Poriete. Konferences dalībnieki aplūkoja izstādi ar interesi, igauņu un lietuvju kolēgi bija atveduši arī savus izdevumus, ko atstāja kā dāvinājumu bibliotēkai Rīgā.

Konferences ietvaros notika arī piemiņas zīmju atklāšana ievērojamiem Rīgas zinātniekiem - ķīmiķim, Nobela prēmijas laureātam Vilhelmam Ostvaldam (1853-1932) un k̦īmiķim analītiḳim, daudzu organisko krāsu reakciju atklājējam analītiskajā ķīmijā Edvīnam Iegrīvem (1878-1944), kuru pētnieciskā darbība lielā mērā saistīta ar RP, RPI un LU. Slēgtajos Lielajos kapos pēc mūsu ierosmes ar mecenāta Itera Latvija prezidenta Jura Savicka finansiālu atbalstu Ostvaldu dzimtas kapa piemineklī iekalti fizikālās k̦īmijas pamatlicēja vecāku, kā arī brāḷa LU mežsaimniecỉbas profesora Eižena Ostvalda vārdi un mūža dati (viņi visi te apbedīti), bet pieminekḷa pakājē uzstādīta piemiṇas plāksne In memoriam pašam V. Ostvaldam, kurš apbedīts Vācijā savas pēdējās mìtnes "Landhaus Energie" parkā. Savukārt plāksne ar Pozenē (Poznaṇā) mirušā Edvīna Iegrīves vārdu uzstādīta pie viṇa svaiṇa k̦īmijas profesora Valdemāra Fišera kapa pieminekḷla. E. Iegrīve atklājis eriohromcianinu $\mathrm{R}$ kā reaǵentu uz alumīnija joniem, cinka nitroprusidu $\mathrm{SO}_{2}$ noteikšanai, hromotropskābi formaldehīda (būtībā - metilspirta) nelielu piemaisījumu atklāšanai un daudzus citus reaǵentus, ko analìtiskajā ḳimijā lieto vēl šodien. Viṇa nopelni Rìgas k̦īmiķu un farmaceitu mācīšanā savulaik bija neapstrīdami, un Iegrīves vārds ir starptautiski pazīstams, reakcijas pieminētas daudzās rokasgrāmatās. Šo pieminas zīmju atklāšana notika 13 oktobrī, piedaloties LZA prezidentam J. Ekmanim, RTU rektoram I. Knētam, Itera Latvija prezidentam J. Savickim, ZA viceprezidentam R. Valteram, akadēmiksim T. Milleram, prof. I. Meirovicam un daudziem konferences dalībniekiem no RTU. Tika godināta arī daudzu ievērojamu zinātnieku un sabiedrisku darbinieku (pirmo RP vadītāju, Dž. Armitsteda, V. Fišera, F. Candera, K. Valdemāra, K. Barona, F. Brīvzemnieka u. c.) piemiña viṇu atdusas vietās. Paskaidrojumus Lielajos kapos sniedza un uzrunas teica I. Knēts, J. Stradiņšs, J. Klētnieks, A. Zigmunde, T. Millers, R. Valters un arhitekts E. Upmanis, kurš veido grāmatu par Lielajiem kapiem un ievērojamu personību apbedījuma vietām tajos.

Sava veida turpinājums Baltijas Zinātņu vēstures konferencei bija RTU 59. Starptautiskās Zinātniskās konferences plenārsēde pārpildītajā RTU aulā, kur pulcējušos ar uzrunu sveica Valsts prezidents Valdis Zatlers. Rektors I. Knēts latviski atkārtoja savu Baltijas konferencē nolasìto lekciju, RTU prorektors aka- 
dēmiķis L. Ribickis stāstīja par RTU pašreiz veicamo zinātnisko pētniecību un rādīja par to filmu. Šajā sēdē RTU muzeja vadītāja A. Zigmunde stāstīja par mēginājumiem atjaunot RPI laikā no 1920. līdz 1958. gadam, bet J. Stradiņš nolasīja referātu par inženiertehniskās inteliǵences veidošanos Rīgā un Latvijā 19.-20. gs., īpaši uzsverot Rīgas Tehniskās biedrības dibināšanas (1858) nozīmi saistībā ar šis biedrības 150 gadiem. Tika aplūkota slavenā izgudrotāja Vernera Sīmensa uzturēšanās Rīgā 1852. gadā, kad viņš te izveidoja pirmo civilo elektromagnētisko telegrāfu Krievijas impērijā (no Bolderājas uz Rīgu).

Ar visu šo pasākumu kopumu ne tikai atzimēti RPI atjaunošanas 50 gadi, bet uzsvērta Latvijas valsts un abu pārējo Baltijas valstu nodibināšanas 90. gadskārta, īpaši rādot augstākās tehniskās izglīīibas vēsturiskās attīstības gaitu, Baltijas valstu sadarbību zinātnē, kopēju zinātṇu vēstures konferenču tradīciju, tāpat Medicīnas vēstures muzeja izveidošanas (kopš 1938) un attīstības nozìmīgumu ne tikai Latvijā, bet arī Baltijā kopumā.

Ir gandarījums, ka arī šajā zinātnes attīstîbai nelabvēlīgajā finanšu un ekonomiskajā situācijā, kad sarūk zinātnes budžets, vēsturiskās tradīcijas tomēr tiek uzturētas un gūst pietiekamu atbalsi sabiedrībā (publicētas Zaigas Kiperes un Gedimina Zemlicka plašas reportāžas par konferenci Latvijas un Lietuvas presē). Šo rindiṇu autoram (kopā ar savu tēvu P. Stradiṇu) ir bijusi laime stāvēt pie šīs tradīcijas šūpuḷa un piedalīties vai visās 23 līdzšinējās konferencēs (izṇemot 1993. un 2006. gadā, bet arī tad konferencē nolasìtas viņa plenārlekcijas), tāpēc īpašs gandarījums, ka šì Paula Stradiṇa ierosme netiek piemirsta vēl pēc 50 gadiem un jaunie igauṇu kolẹǵi pašreiz ir gatavi to arī turpināt.

Īpaši jāuzsver, ka konferenču rīkošana pāriet jaunākās paaudzes zinātnieku rokās (arī 23. konferences rīkošanas galveno smagumu iznesa divas jaunas zinātṇu doktores A. Zigmunde un M. Pozemkovska, kas nesen promovējušāa ar disertācijām par medicīnas un pedagoǵijas vēsturi). Tas apliecina, ka arī šajā jomā vēstures stafete tiek nodota tālāk un Baltijas medicīnas un zinātṇu vēstures pētnieku sadarbībai, ko aizsāka Pauls Stradinšs pretrunīgajos un grūtajos 1950. gados, paredzams cienīgs turpinājums.

Diemžēl drīz pēc konferences Latvijā sākās īpaši smaga finanšu un ekonomiskā krīze, kas sāpīgi skāra arī zinātni, un ne visi konferences ieteikumi varēja tikt īstenoti. Tomēr, neraugoties uz krīzi, labā kvalitātē izdota J. Stradiṇa lielā monogrāfija "Zinātnes un augstskolu sākotne Latvijā". 2010. g. 8.-9. oktobrī Tallinas Tehnologiskajā universitātē paredzēts noturēt 24. Baltijas Zinātṇu vēstures konferenci.

\section{LZA prezidenta Jura Ekmaṇa uzruna 23. Baltijas Zinātṇu vēstures konferencei \\ (2008. gada 9. oktobrī)}

Godātie 23. Starptautiskās Baltijas zinātṇu vēstures konferences dalïbnieki, organizatori un viesi! 


\section{J. Stradiňš}

Esmu gandarìts par zinātnieku interesi un atsaucību, pievēršoties visdažādāko zinātṇu nozares vēstures pētniecībai. Šĩ aktivitāte vēlreiz apliecina Eiropas Savienības attīstības politikā vairākkārt uzsvērto tēzi par "zinātnes sabiedrības" veidošanas aktualitāti ES dalībvalstīs. Tiesa, šì zinātnes sabiedrība programmatiskajos dokumentos vairāk domāta kā mūsdienīga, ar augstu izglìtības līmeni bruṇota sabiedrība, tāda, kura spēj attīstìt ražošanu ar augstu pievienoto vērtību.

Taču tāda nākotne nav domājama bez zinātnes vēstures zināšanām, bet šīs zināšanas - bez sistemātiskas, uz pirmavotiem balstìtas pētniecības. Simboliski, ka Latvijas, Lietuvas un Igaunijas valsiskuma vaidošanās 90 . gadā esam sapulcējušies savu zinātnes un augstākās izglìīibas attīstības problēmu analīzei, izcilu zinātnieku darbības atcerei un godināšanai. Tieši tagad îpaša uzmanība tiek veltīta nacionālo zinātṇu un centru attīstībai.

Baltijas zinātnes vēsturnieku konferences notiek jau 50 gadus, - paldies par ierosmi akadēmiķim Paulam Stradiṇam un par aktivitāti akadēmiḳim Jānim Straduņam! Šis gads, iezīmējot pusgadsimtu, ir nozīmīgs RTU un Paula Stradiṇa Medicīnas vēstures muzeja dzīvē.

Par šo acīmredzamo tēmu daudzpusību, par laikmeta peripetiju atstāto ietekmi uz zinātnes un augstākās izglìtības attīstību, par izcilajām, radošajām zinātnes personībām tālākā un tuvākā pagātnē, par zinātnisko skolu veidošanos, par Baltijas cel̦u uz Eiropu un Eiropas ietekmi Baltijā, - par to būtu vērts izveidot kopīgus darbus vēsturiskās pieredzes apkopošanai un nākotnes perspektīvu apzināšanai. To jums no sirds novēlu!

\section{Latvijas Republikas izglītības un zinātnes ministres profesores Tatjanas Koḳes vēstījums \\ 23. Baltijas Zinātṇu vēstures konferencei}

Honoured Mr Jānis Stradiņš, Academician, the President of the Baltic Association of History and Philosophy of Sciences!

Distinguished participants of the 23rd International Baltic Conference on the History of Science!

It is a true pleasure and honour to welcome you all here today at the 50th anniversary of Baltic movement of historians of Sciences! Let me note the fact or even historical congruence, - today anniversary conference takes place here - in Latvia, and is close to anniversary of our state.

The history in general is used to be consired as a great teacher of life and at the same great teacher is the history of science. And I appeal to aware and honour this great teacher of life!

The history of sciences is a very rich source of knowledge for all society, because it facilitates the understanding of people about historical and cultural values, which certainly appear during the process of development of science! 
Let me note with satisfaction that historians of various scientific fields are involved starting from ancient history issues to the most important contemporary events. And this 23rd International Baltic Conference on the History of Science is also devoted to the fact of continuity and contemporarity.

This contemporary emphasizes in research awake and strengthen interest in the Baltic history of science, as well as - help us better notice the ways of development of scientific fields.

I would like to Express my deepest gratitude to our Academician Jānis Stradiņš for the excellent leadership of Baltic historians of science movement during all 50 years.

I wish you an efficient and creative work at conference!

Yours sincerely,

Minister of Education and Science, Professor Tatjana Koḳe

October 9, 2008

\section{3rd International Baltic Conference on the History of Science (Summary)}

\section{By Jānis Stradiñ̌̌}

A short account about the 23rd International Baltic Conference on the History of Science which took place in Riga, 9-10 October, 2008. It was organized by the Association of the history and philosophy of sciences of the Baltic States, Latvian Academy of Science, Riga Technical University, University of Latvia and Pauls Stradiņš Museum of History of Medicine. The conference commemorated 50 years of the tradition of the Baltic conferences; the first one was organized in 1958, June 6-7 by Prof. Pauls Stradiňš. The 23rd conference was attended by historians of science and medicine from 11 countries (Germany, Great Britain, Austria, Portugal, Russia, Ukraine, Byelorus, Estonia, Lithuania, Latvia). Two plenary sessions and six section sessions have been held. Among other events a memorial session devoted to Prof. P. Stradiņš and a memorial session devoted to the late director of P. Stradiňš Museum - Doc. Dr. K. E. Arons have been held. The 50th anniversary of the organization of the Museum of history of medicine has been commemorated in the conference, as weld. Some memorials to outstanding chemists - W. Ostwald and E. Eegriwe have been unveiled in Rìga Big Cemetery during the conference.

Jānis Stradiņ̌š, profesors, Dr. habil. chem., Dr. hist. h.c. stradins@lza.lv 